Article

\title{
Lochmolins A-G, New Sesquiterpenoids from the Soft Coral Sinularia lochmodes
}

\author{
Yen-Ju Tseng ${ }^{1}$, Kuo-Ping Shen ${ }^{2}$, Hui-Li Lin ${ }^{3}$, Chiung-Yao Huang ${ }^{1}$, Chang-Feng Dai ${ }^{4}$ and \\ Jyh-Horng Sheu ${ }^{1,5, *}$
}

1 Department of Marine Biotechnology and Resources, National Sun Yat-sen University, Kaohsiung 804, Taiwan; E-Mails: pit0424@yahoo.com.tw (Y.-J.T.); betty8575@yahoo.com.tw (C.-Y.H.)

2 Department of Nursing, Meiho University, Pingtung 912, Taiwan; E-Mail: x00002148@meiho.edu.tw

3 Department of Food and Nutrition, Meiho University, Pingtung 912, Taiwan; E-Mail: x00002165@meiho.edu.tw

4 Institute of Oceanography, National Taiwan University, Taipei 112, Taiwan; E-Mail: corallab@ntu.edu.tw

5 Division of Marine Biotechnology, Asia-Pacific Ocean Research Center, National Sun Yat-sen University, Kaohsiung 804, Taiwan

* Author to whom correspondence should be addressed; E-Mail: sheu@mail.nsysu.edu.tw; Tel.: +886-7-525-2000 (ext. 5030); Fax: +886-7-525-5020.

Received: 15 June 2012; in revised form: 6 July 2012 / Accepted: 13 July 2012 /

Published: 20 July 2012

\begin{abstract}
Seven new sesquiterpenoids, lochmolins A-G (1-7), were isolated from a Taiwanese soft coral Sinularia lochmodes. The structures of these metabolites were elucidated by extensive spectroscopic study. Compounds 1-4 were found to inhibit the accumulation of the LPS-induced pro-inflammatory COX-2 protein in RAW264.7 macrophage cells.
\end{abstract}

Keywords: soft coral; Sinularia lochmodes; sesquiterpenes; aromadendrane; germacrane

\section{Introduction}

Soft corals of the genue Sinularia have been discovered to be a rich source of terpenes [1]. Previously, we discovered a 9,11-secosterol [2] and diterpenes-related compounds [3,4] from the soft 
coral Sinularia lochmodes collected off the coast of southern Taiwan. Our current chemical investigation of the soft coral $S$. lochmodes, collected from the northeastern coast of Taiwan, has led to the isolation of six new aromadendrane-type [5-7] sesquiterpenoids lochmolins A-F (1-6), and a new germacrane [8] sesquiterpenoid lochmolin G (7) (Chart 1). The relative structures of the new metabolites were established by extensive spectroscopic analysis. The ability of 1-7 to inhibit up-regulation of the pro-inflammatory iNOS (inducible nitric oxide synthase) and COX-2 (cyclooxygenase-2) proteins in LPS (lipopolysaccharide)-stimulated RAW264.7 macrophage cells was also evaluated.

Chart 1. Structures of metabolites 1-7.
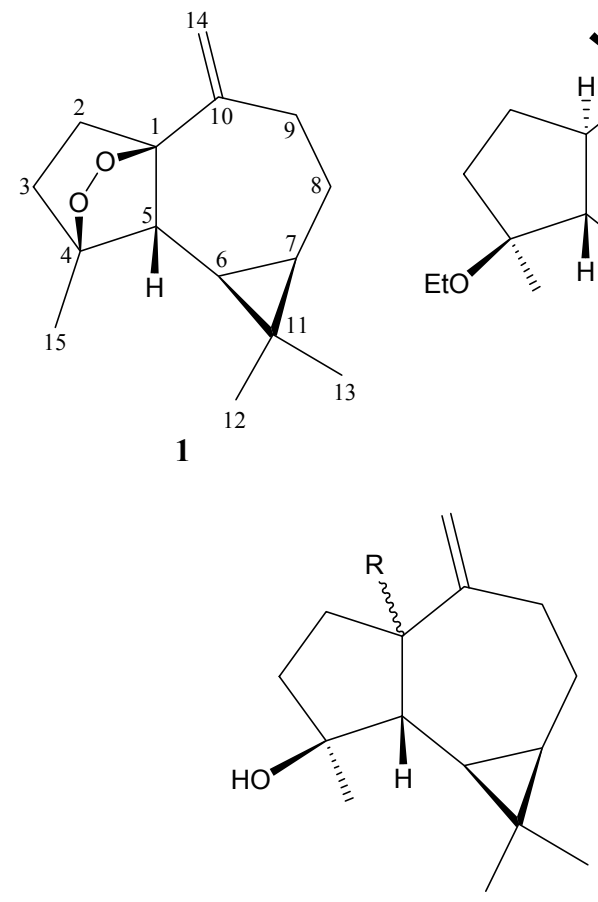

$4 \mathrm{R}=\beta-\mathrm{OOH}$

$5 \mathrm{R}=\alpha-\mathrm{OOH}$

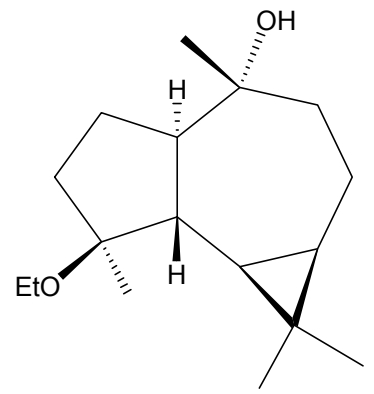

2

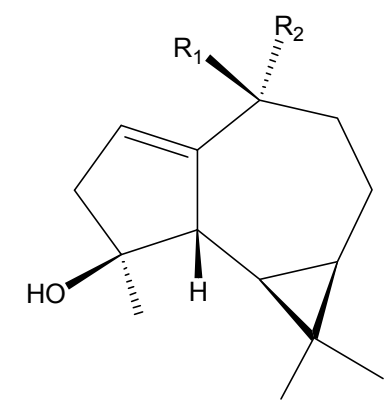

$3 \mathrm{R}_{1}=\mathrm{OOH}, \mathrm{R}_{2}=\mathrm{CH}_{3}$ $6 \mathrm{R}_{1}=\mathrm{CH}_{3}, \mathrm{R}_{2}=\mathrm{OH}$

\section{Results and Discussion}

Lochmolin A (1) was isolated as a colorless oil. Its molecular formula, $\mathrm{C}_{15} \mathrm{H}_{22} \mathrm{O}_{2}$, was established by HREIMS ( $\left.\mathrm{m} / \mathrm{z} 234.1620,[\mathrm{M}]^{+}\right)$, implying five degrees of unsaturation. The ${ }^{13} \mathrm{C}$ NMR spectral data of 1 (Table 1), showed the presence of 15 carbon atoms, including three methyls $\left(\delta_{\mathrm{C}} 28.5,24.8\right.$, and 16.2) and two quaternary $\mathrm{sp}^{3}$ oxycarbons $\left(\delta_{\mathrm{C}} 89.3\right.$ and 83.1$)$, as assigned by the DEPT spectrum, suggesting the oxygenated sesquiterpenoid nature of 1 . The NMR signals (Tables 1 and 2) observed at $\delta_{\mathrm{C}} 112.7$ $\left(\mathrm{CH}_{2}\right)$ and $151.5(\mathrm{C}), \delta_{\mathrm{H}} 5.02$ and 4.89 (each $\left.1 \mathrm{H}, \mathrm{s}\right)$ showed the presence of one 1,1-disubstituted double bond. Thus, the tetracyclic structure of 1 was revealed. In the ${ }^{1} \mathrm{H}-{ }^{1} \mathrm{H}$ COSY spectrum it was possible to identify two different structural units, which were assembled with the assistance of an HMBC experiment. Key HMBC correlations of $\mathrm{H}_{2}-2$ to $\mathrm{C}-1, \mathrm{C}-3, \mathrm{C}-4$ and C-5; $\mathrm{H}_{3}-12$ to C-6, C-7, $\mathrm{C}-11$ and $\mathrm{C}-13 ; \mathrm{H}_{3}-13$ to $\mathrm{C}-6, \mathrm{C}-7, \mathrm{C}-11$ and $\mathrm{C}-12 ; \mathrm{H}_{2}-14$ to $\mathrm{C}-1, \mathrm{C}-9$ and $\mathrm{C}-10 ; \mathrm{H}_{3}-15$ to $\mathrm{C}-3, \mathrm{C}-4$ and $\mathrm{C}-5$ permitted the establishment of the aromadendrane-type skeleton of $\mathbf{1}$ (Figure 1). Furthermore, the two additional oxygen atoms could be used to form an endoperoxide bridge in the cyclopentane moiety of the molecule from the downfield chemical shifts of the sp ${ }^{3}$ carbons $\mathrm{C}-1(\delta 89.3, \mathrm{C})$ and $\mathrm{C}-4(\delta 83.1, \mathrm{C})$. 
The presence of a cyclopropane was further confirmed by the upfield chemical shifts of H-6 $(\delta 0.08)$ and $\mathrm{H}-7$ ( $\delta 0.54)$.

Table 1. ${ }^{13} \mathrm{C}$ NMR spectroscopic data for compounds $\mathbf{1}-\mathbf{7}$.

\begin{tabular}{cccccccc}
\hline & $\mathbf{1}$ & $\mathbf{2}$ & $\mathbf{3}$ & $\mathbf{4}$ & $\mathbf{5}$ & $\mathbf{6}$ & $\mathbf{7}$ \\
\hline 1 & 89.3 & 47.3 & 150.1 & 101.1 & 96.8 & 155.2 & 41.1 \\
2 & 36.0 & 23.4 & 125.2 & 29.6 & 29.1 & 117.3 & 23.4 \\
3 & 38.9 & 37.8 & 45.3 & 39.0 & 39.6 & 45.1 & 40.8 \\
4 & 83.1 & 79.3 & 82.2 & 81.7 & 81.0 & 82.2 & 73.0 \\
5 & 56.2 & 49.9 & 52.6 & 55.2 & 57.3 & 53.8 & 143.1 \\
6 & 27.4 & 25.1 & 27.4 & 26.6 & 21.4 & 27.2 & 128.4 \\
7 & 23.0 & 26.2 & 27.0 & 24.2 & 27.6 & 27.4 & 57.9 \\
8 & 20.9 & 20.1 & 18.8 & 20.6 & 25.2 & 20.2 & 24.7 \\
9 & 31.4 & 40.3 & 38.3 & 33.1 & 34.1 & 43.4 & 129.5 \\
10 & 151.5 & 80.4 & 83.0 & 147.1 & 150.7 & 73.9 & 131.9 \\
11 & 18.4 & 19.0 & 20.3 & 18.5 & 19.9 & 19.0 & 71.9 \\
12 & 28.5 & 28.9 & 28.5 & 28.4 & 28.6 & 28.3 & 26.8 \\
13 & 16.2 & 16.4 & 16.0 & 16.0 & 15.7 & 16.0 & 26.9 \\
14 & 112.7 & 25.7 & 23.0 & 116.2 & 113.3 & 27.3 & 16.6 \\
15 & 24.8 & 18.8 & 22.9 & 24.3 & 27.6 & 22.4 & 23.4 \\
OEt & & 55.2 & & & & & \\
& & 16.3 & & & & & \\
\hline
\end{tabular}

Table 2. ${ }^{1} \mathrm{H}$ NMR spectral data for compounds $\mathbf{1}-\mathbf{4}$.

\begin{tabular}{rcccc}
\hline & $\mathbf{1}$ & $\mathbf{2}$ & $\mathbf{3}$ & $\mathbf{4}$ \\
\hline 1 & & $1.05 \mathrm{~m}$ & & \\
2 & $2.01 \mathrm{~m}$ & $1.70 \mathrm{~m}$ & $5.66 \mathrm{~d}(3.0)$ & $2.19 \mathrm{~m}$ \\
& $2.45 \mathrm{~m}$ & $1.80 \mathrm{~m}$ & & $2.46 \mathrm{~m}$ \\
3 & $1.95 \mathrm{~m}$ & $1.62 \mathrm{~m}$ & $2.27 \mathrm{dd}(17.0,3.0)$ & $1.91 \mathrm{~m}$ \\
& $2.05 \mathrm{~m}$ & $1.72 \mathrm{~m}$ & $2.61 \mathrm{~d}(17.0)$ & $1.97 \mathrm{~m}$ \\
5 & $1.77 \mathrm{~d}(12.0)^{a}$ & $2.38 \mathrm{dd}(11.0,5.5)$ & $2.31 \mathrm{~d}(11.0)$ & $1.68 \mathrm{~d}(11.5)$ \\
6 & $0.08 \mathrm{dd}(12.0,10.0)$ & $0.64 \mathrm{~m}$ & $0.27 \mathrm{dd}(11.0,9.5)$ & $0.19 \mathrm{dd}(11.5,9.0)$ \\
7 & $0.54 \mathrm{dd}(17.0,10.0)$ & $0.67 \mathrm{~m}$ & $0.53 \mathrm{~m}$ & $0.58 \mathrm{~m}$ \\
8 & $1.48 \mathrm{~m}$ & $0.89 \mathrm{~m}$ & $1.46 \mathrm{~m}$ & $1.40 \mathrm{~m}$ \\
& $1.87 \mathrm{~m}$ & $1.86 \mathrm{~m}$ & $1.65 \mathrm{~m}$ & $1.80 \mathrm{~m}$ \\
9 & $2.30 \mathrm{~m}$ & $1.48 \mathrm{~m}$ & $1.64 \mathrm{~m}$ & $2.35 \mathrm{~m}$ \\
& $2.65 \mathrm{~m}$ & $1.68 \mathrm{~m}$ & $1.92 \mathrm{dd}(14.5,5.5)$ & $2.63 \mathrm{~m}$ \\
12 & $1.00 \mathrm{~s}$ & $1.05 \mathrm{~s}$ & $1.02 \mathrm{~s}$ & $1.02 \mathrm{~s}$ \\
13 & $1.06 \mathrm{~s}$ & $0.97 \mathrm{~s}$ & $1.12 \mathrm{~s}$ & $5.08 \mathrm{~s}$ \\
14 & $4.89 \mathrm{~s}$ & $1.24 \mathrm{~s}$ & $1.49 \mathrm{~s}$ & $5.14 \mathrm{~s}$ \\
& $5.02 \mathrm{~s}$ & & & $1.27 \mathrm{~s}$ \\
15 & $1.30 \mathrm{~s}$ & $1.05 \mathrm{~s}$ & $1.40 \mathrm{~s}$ & \\
16 & & $3.40 \mathrm{~m}$ & & \\
17 & & $3.44 \mathrm{~m}$ & & \\
$10-\mathrm{OOH}$ & & $1.12 \mathrm{t}(7.0)$ & & \\
\hline
\end{tabular}


Figure 1. Selected ${ }^{1} \mathrm{H}_{-}{ }^{1} \mathrm{H} \operatorname{COSY}(-)$ and $\operatorname{HMBC}(\rightarrow)$ correlations of $\mathbf{1 - 4}$ and $\mathbf{7 .}$
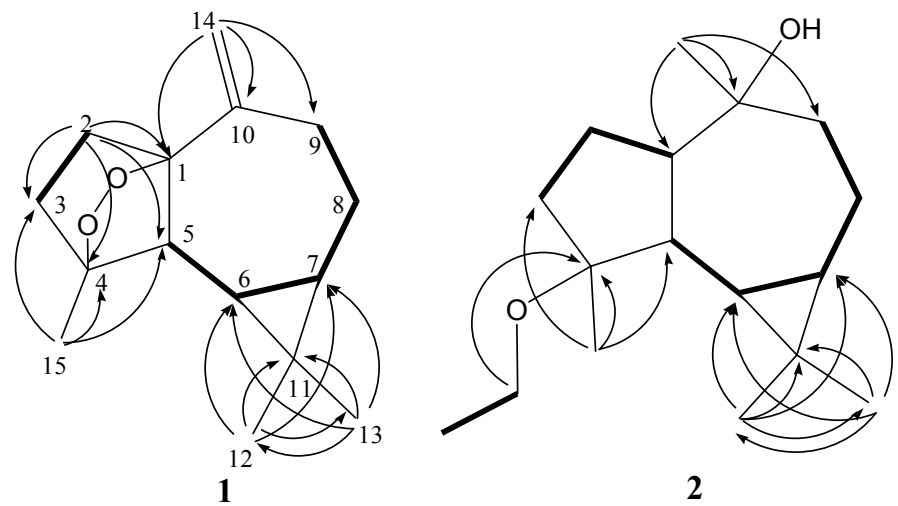

2

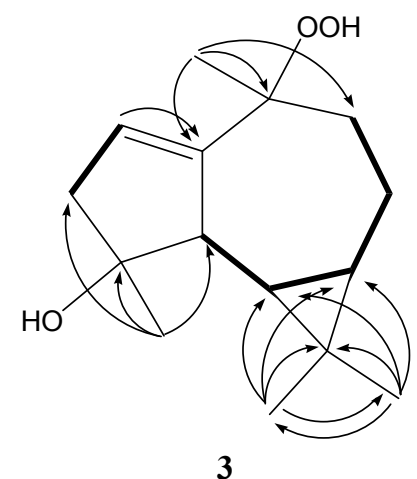

3

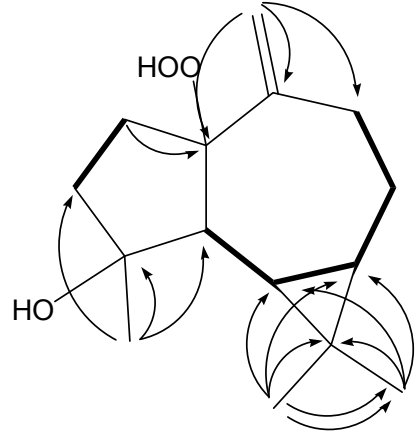

4

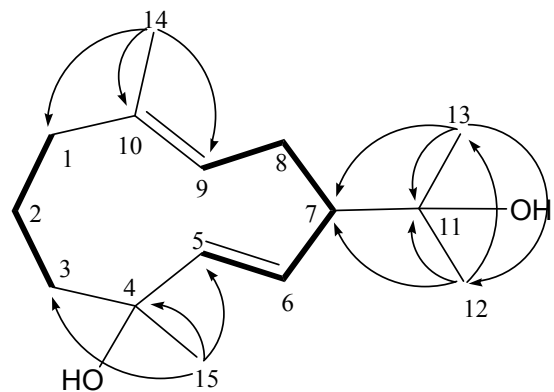

7

The relative configurations of five chiral centers at C-1, C-4, C-5, C-6, and C-7 in 1 were elucidated by NOE analysis (Figure 2). It was found that $\mathrm{H}-6$ showed $\mathrm{NOE}$ correlations with $\mathrm{H}-7, \mathrm{H}_{3}-12$, and $\mathrm{H}_{3}-15$; $\mathrm{H}-7$ ( $\delta$ 0.54) showed NOE correlations with $\mathrm{H}_{3}-12$; and $\mathrm{H}-5(\delta 1.77)$ showed NOE correlations with $\mathrm{H}_{3}-13$. Thus $\mathrm{H}-6, \mathrm{H}-7$, and $\mathrm{H}_{3}-15$ were assumed to be positioned on the $\alpha$ face, and $\mathrm{H}-5$ was assumed to be positioned on the $\beta$ face. On the basis of these results, lochmolin A (1) was found to possess the $\left(1 R^{*}, 4 S^{*}, 5 R^{*}, 6 R^{*}, 7 R^{*}\right)$ configuration.

Figure 2. Key NOESY correlations for $\mathbf{1}-\mathbf{3}$.

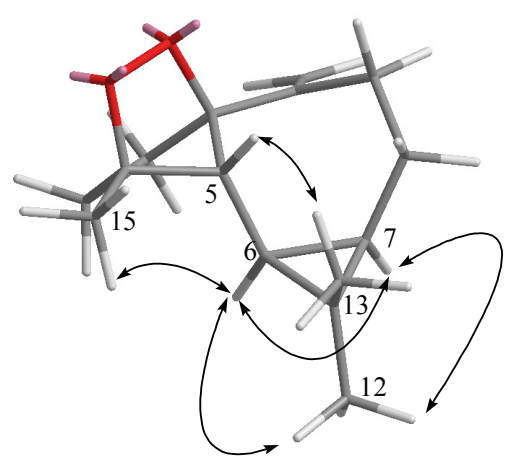

1

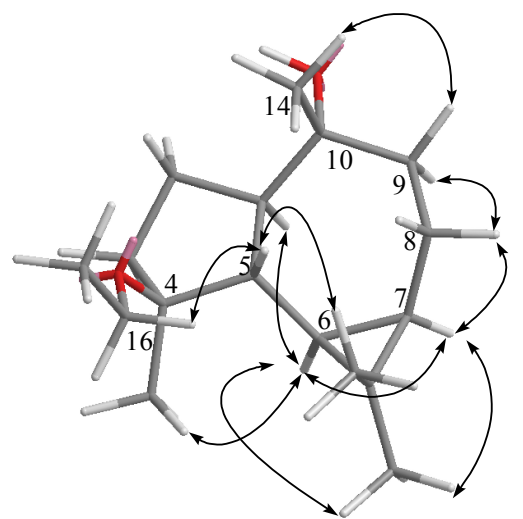

2

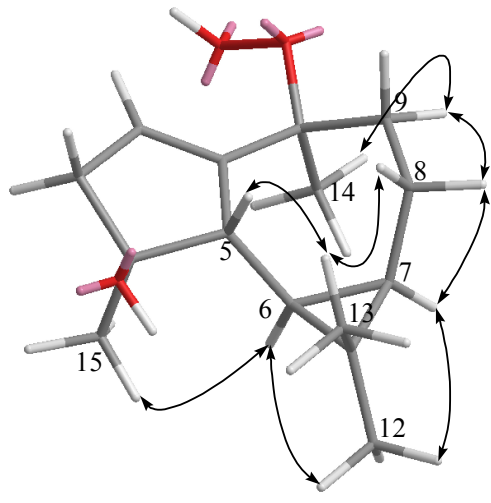

3

Lochmolin B (2) was obtained as a colorless oil. HRESIMS showed the molecular formula $\mathrm{C}_{17} \mathrm{H}_{30} \mathrm{O}_{2}$, requiring three degrees of unsaturation. The IR spectrum suggested the presence of hydroxy group $\left(3437 \mathrm{~cm}^{-1}\right)$. The $3 \mathrm{H}$ triplet appearing at $\delta 1.12(J=7.0 \mathrm{~Hz})$ in the ${ }^{1} \mathrm{H}$ NMR spectrum and the 
methylene carbon signal at $\delta 55.2$ in the ${ }^{13} \mathrm{C}$ NMR spectrum were ascribable to an ethoxy group. Comparison of the NMR data (Table 1) of $\mathbf{2}$ with those of $\mathbf{1}$ also showed the aromadendrane skeleton of 2. In the 2D NMR spectra, including ${ }^{1} \mathrm{H}-{ }^{1} \mathrm{H}$ COSY and HMBC (Figure 1), three segregate consecutive proton spin systems, $\mathrm{H}-1$ to $\mathrm{H}_{2}-3, \mathrm{H}-5$ to $\mathrm{H}_{2}-9$, and $\mathrm{CH}_{2}$ to $\mathrm{CH}_{3}$ of an ethoxy group, were found in the ${ }^{1} \mathrm{H}-{ }^{1} \mathrm{H}$ COSY spectrum. The detailed analysis of HMBC correlations further established the planar structure of $\mathbf{2}$. The relative structure of $\mathbf{2}$ was elucidated by the analysis of NOE correlations, as shown in Figure 2. It was found that H-6 $(\delta 0.64, \mathrm{~m})$ showed NOE interactions with $\mathrm{H}-1(\delta 1.05, \mathrm{~m})$, $\mathrm{H}-7(\delta 0.67, \mathrm{~m}), \mathrm{H}_{3}-12(\delta 1.05, \mathrm{~s})$ and $\mathrm{H}_{3}-15(\delta 1.05, \mathrm{~s})$, and $\mathrm{H}-7(\delta 0.67, \mathrm{~m})$ showed NOE correlations with $\mathrm{H}-8 \alpha(\delta 1.86, \mathrm{~m})$ and $\mathrm{H}_{3}-12(\delta 1.05, \mathrm{~s})$; therefore, assuming the $\alpha$-orientation of $\mathrm{H}-1$, all of $\mathrm{H}-6$, $\mathrm{H}-7, \mathrm{H}_{3}-12$ and $\mathrm{H}_{3}-15$ should also be positioned on the $\alpha$ face. One of the methylene protons at C-9 $(\delta 1.68, \mathrm{~m})$ exhibited NOE correlations with $\mathrm{H}-8 \alpha(\delta 1.86, \mathrm{~m})$ and was characterized as $\mathrm{H}-9 \alpha$, while the other $(\delta 1.48, \mathrm{~m})$ was assigned as $\mathrm{H}-9 \beta$. NOE correlations observed between $\mathrm{H}-9 \beta$ and $\mathrm{H}_{3}-14$, and $\mathrm{H}-5$ with both $\mathrm{H}_{3}-13$ ( $\delta 0.97, \mathrm{~s}$ ) and protons of $\mathrm{OCH}_{2}$, reflected the $\beta$-orientation of $\mathrm{H}-5$ and $\mathrm{H}_{3}-14$. On the basis of the above findings (Figure 2), the relative structure of lochmolin B (2) was determined.

The HRESIMS spectrum of lochmolin C (3) exhibited a molecular ion peak at $\mathrm{m} / \mathrm{z} 275.1622$ $\left([\mathrm{M}+\mathrm{Na}]^{+}\right)$, consistent with the molecular formula $\mathrm{C}_{15} \mathrm{H}_{24} \mathrm{O}_{3}$ and implying four degrees of unsaturation. The IR absorption of 3 also revealed the presence of hydroxy group $\left(3437 \mathrm{~cm}^{-1}\right)$. Comparison of the NMR data (Tables 1 and 2) of $\mathbf{3}$ with those of $\mathbf{2}$ showed the appearance of an additional trisubstituted double bond in 3. The NMR chemical shifts for C-4 and C-10 of 3 ( $\delta 82.2$ and $\delta 83.0$, respectively), were found to be shifted downfield in comparison with the analogous data of 2 ( $\delta 79.3$ and $\delta 80.4$ ), suggesting that the 4-OEt and 10-OH of $\mathbf{2}$ might be replaced by the $4-\mathrm{OH}$ and $10-\mathrm{OOH}$ $(\delta 7.64, \mathrm{~s})$ in 3 . This could be confirmed from the carbon shifts of both hydroxylated quaternary carbons C-4 ( $\delta$ 82.2) and C-10 ( $\delta$ 73.9) of 6 (latter discussed) which showed the identical chemical shift of C-4 of compound 3. By analysis of 2D NMR spectra (HMQC, ${ }^{1} \mathrm{H}-{ }^{1} \mathrm{H}$ COSY, and HMBC), compound $\mathbf{3}$ was shown to possess the same molecular framework as that of $\mathbf{2}$. Investigation of the NOESY spectrum of 3 (Figure 2) revealed the NOE interactions of H-7 $(\delta 0.53, \mathrm{~m})$ with $\mathrm{H}-8 \alpha$ $(\delta 1.65, \mathrm{~m}), \mathrm{H}-8 \alpha$ with $\mathrm{H}-9 \alpha(\delta 1.92, \mathrm{dd}, J=14.5,5.5 \mathrm{~Hz})$, and $\mathrm{H}-9 \alpha$ with $\mathrm{H}_{3}-14(\delta 1.49, \mathrm{~s})$, suggesting the $\alpha$-orientation of $\mathrm{H}_{3}-14$. Further analysis of other NOE interactions revealed that 3 possessed the same relative configurations at C-4, C-5, C-6, and C-7 as those of 2.

Lochmolin D (4) was also isolated as a colorless oil with a molecular formula of $\mathrm{C}_{15} \mathrm{H}_{24} \mathrm{O}_{3}$. The ESIMS and NMR spectroscopic data of 4 (Table 1) showed the presence of a hydroxy and hydroperoxy moiety $[\delta 81.7$ (C), and 101.1 (C)]. Comparison of the NMR data of 4 with those $\mathbf{1}$ revealed that the two differences between both compounds were the replacement of the endoperoxide bridge moiety at C-1 and C-4 in $\mathbf{1}$ by the hydroxy at C-4 and the hydroperoxy at C-1 in $\mathbf{4}$. The relative structure of 4 was elucidated by the analysis of NOE correlations, as shown in Figure 3. It was found that H-6 $(\delta 0.19, \mathrm{dd}, J=11.5,9.0 \mathrm{~Hz})$ showed NOE interactions with $\mathrm{H}-7(\delta 0.58, \mathrm{~m}), \mathrm{H}_{3}-12(\delta 1.02, \mathrm{~s})$, and $\mathrm{H}_{3}-15(\delta 1.27, \mathrm{~s})$, but not with $\mathrm{H}-5(\delta 1.68, \mathrm{~d}, J=9.0 \mathrm{~Hz})$; therefore, assuming an $\alpha$-orientation of $\mathrm{H}-6, \mathrm{H}-7$ and $\mathrm{H}_{3}-15$ should also be positioned on the $\alpha$ face, and $\mathrm{H}-5$ should be placed on the $\beta$ face. One of the $\mathrm{sp}^{3}$ methylene proton at C-2 $(\delta 2.19, \mathrm{~m})$ exhibited NOE correlations with one of the $\mathrm{sp}^{2}$ methylene proton at $\mathrm{C}-14(\delta 5.08, \mathrm{~s})$, suggesting the $\beta$-orientation of $1-\mathrm{OOH}$ by inspecting the molecular model of 4 . If the 1-OOH was placed on the $\alpha$ face as in the case of 5 (latter discussed), both 
protons at C-2 were found to exhibit NOE correlations with one of the $\mathrm{sp}^{2}$ proton at $\mathrm{C}-14$ by molecular modeling study. On the basis of the above findings, the relative structure of $\mathbf{4}$ was determined.

Figure 3. Key NOESY correlations for 4-6.

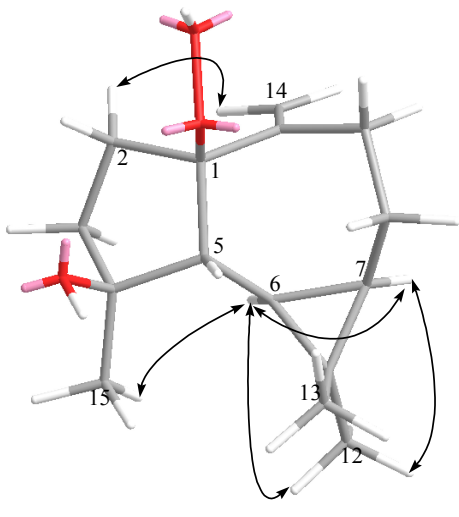

4

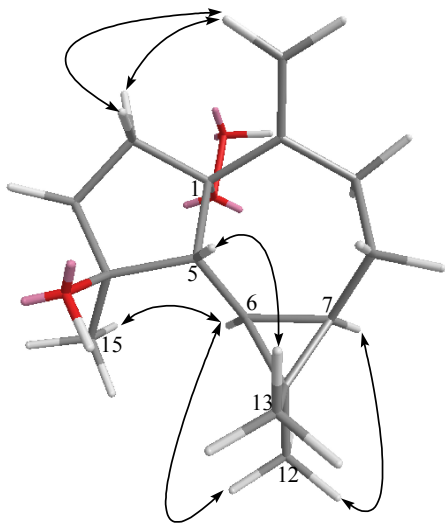

5

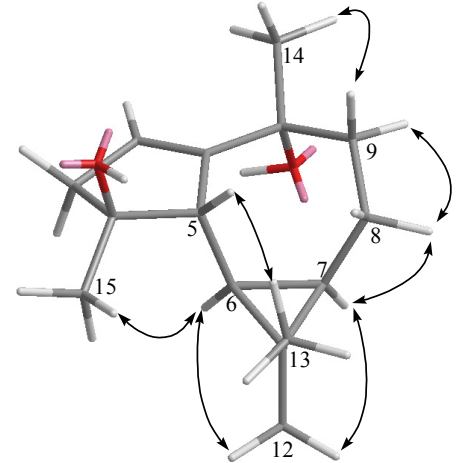

6

HRESIMS and NMR spectroscopic data (Tables 1 and 3) revealed that lochmolin E (5) has the same molecular formula, $\mathrm{C}_{15} \mathrm{H}_{24} \mathrm{O}_{3}$, as that of 4. By analysis of $2 \mathrm{D}$ NMR spectra, including ${ }^{1} \mathrm{H}-{ }^{1} \mathrm{H}$ COSY, HMQC, and HMBC, compound $\mathbf{5}$ was shown to possess the same molecular framework as that of $\mathbf{4}$. Comparison of the NMR data of 5 with those of $\mathbf{4}$ revealed that the only difference between the compounds was the replacement of the $\beta$-hydroperoxy group at $\mathrm{C}-1$ in $\mathbf{4}$ by the $\alpha$-hydroperoxy group in 5. From the NOESY spectrum, it was found both protons of $\mathrm{H}_{2}-2$ (each $1 \mathrm{H}, \delta 2.19$ and 2.24, m) showed NOE interactions with one of the $\mathrm{sp}^{2}$ methylene proton at $\mathrm{C}-14(\delta 4.97, \mathrm{~s})$, suggesting the $\alpha$-orientation of $1-\mathrm{OOH}$ by investigation of the molecular model (Figure 3 ). Further analysis of other NOE interactions revealed that 5 possesses the same relative configurations at C-4, C-5, C-6, and C-7, as those of $\mathbf{4}$. Therefore, 5 was found to be the C-1 epimer of 4 .

Lochmolin F (6) was obtained as a colorless oil and exhibited an ion peak at $m / z 236.1774\left([\mathrm{M}]^{+}\right)$ by HREIMS, appropriate for the molecular formula $\mathrm{C}_{15} \mathrm{H}_{24} \mathrm{O}_{2}$. Comparison of the NMR data of 6 with those of 3 revealed that the only difference between both compounds was the replacement of a hydroperoxy group at C-10 in $\mathbf{3}$ by the hydroxy moiety in $\mathbf{6}$. This was evidenced from the upfield chemical shifts induced by a hydroxy group at $\mathrm{C}-10(\delta \mathrm{c} 73.9)$ and $\mathrm{H}_{3}-14\left(\delta_{\mathrm{H}} 1.32\right)$ in 6 relative to those of 3. The relative configuration of $\mathbf{6}$ was determined by analysis of key NOE correlations (Figure 3 ).

The metabolite lochmolin G (7) was also obtained as a colorless oil. Its HRESIMS spectroscopic data $\left(\mathrm{m} / z\right.$ 261.1828) suggested the molecular formula $\mathrm{C}_{15} \mathrm{H}_{26} \mathrm{O}_{2}$, requiring three degrees of unsaturation. IR absorption was observed at $3303 \mathrm{~cm}^{-1}$, suggesting the presence of hydroxy group in 7 . In the ${ }^{13} \mathrm{C}$ NMR and DEPT spectra (Table 1), signals of four methyls, four $\mathrm{sp}^{3}$ methylenes, one $\mathrm{sp}^{3}$ methine, three $\mathrm{sp}^{2}$ methines, two $\mathrm{sp}^{3}$ quaternary carbons, and one $\mathrm{sp}^{2}$ quaternary carbons were observed. The ${ }^{13} \mathrm{C}$ NMR data of 7 (Table 1) revealed the presence of one trisubstituted and one 1,2-disubstituted carbon-carbon double bond [ $\delta \mathrm{c} 131.9(\mathrm{C})$ and $129.5(\mathrm{CH}) ; 143.1(\mathrm{CH})$ and $128.4(\mathrm{CH})$ ]. Two hydroxylated carbons ( $\delta \mathrm{c} 73.0$ and 71.9) were also assigned from the ${ }^{13} \mathrm{C}$ NMR spectrum. The remaining one degree of unsaturation identified 7 as a cyclic compound. The planar structure of metabolite 7 was elucidated by analysis of ${ }^{1} \mathrm{H}-{ }^{1} \mathrm{H}$ COSY and $\mathrm{HMBC}$ correlations (Figure 1). Key HMBC correlations from $\mathrm{H}_{3}-12$ to 
C-7, C-11, and $\mathrm{C}-13 ; \mathrm{H}_{3}-13$ to $\mathrm{C}-7, \mathrm{C}-11$, and $\mathrm{C}-12 ; \mathrm{H}_{3}-14$ to $\mathrm{C}-1, \mathrm{C}-9$, and $\mathrm{C}-10 ; \mathrm{H}_{3}-15$ to $\mathrm{C}-3, \mathrm{C}-4$, and $\mathrm{C}-5$ permitted the establishment of the germacrane skeleton. In the NOESY spectrum of 7 (Figure 4), observation of the NOE correlations between $\mathrm{H}-6$ and $\mathrm{H}_{3}-12, \mathrm{H}_{3}-13$ and $\mathrm{H}_{3}-15$, and between $\mathrm{H}-5$ and $\mathrm{H}-7$, suggested that $\mathrm{H}_{3}-15$ is $\alpha$-oriented, and $\mathrm{H}-7$ is $\beta$-oriented. The $E$ geometries were assigned for the 5,6- and 9,10- double bonds on the basis of the upfield chemical shift of C-14 ( $\delta$ 16.6) and the large coupling constant between H-5 and H-6 $(J=16.0 \mathrm{~Hz})$. Therefore, the relative structure of 7 was established.

Table 3. ${ }^{1} \mathrm{H}$ NMR spectral data for compounds 5-7.

\begin{tabular}{cccc}
\hline & $\mathbf{5}$ & $\mathbf{6}$ & $\mathbf{7}$ \\
\hline 1 & & & $2.24 \mathrm{~m}$ \\
& & & $2.29 \mathrm{~m}$ \\
2 & $2.19 \mathrm{~m}$ & $5.54 \mathrm{dd}(3.0,1.5)^{a}$ & $1.61 \mathrm{~m}$ \\
& $2.24 \mathrm{~m}$ & $2.25 \mathrm{dd}(16.5,3.0)$ & $1.65 \mathrm{~m}$ \\
3 & $1.78 \mathrm{~m}$ & $2.55 \mathrm{~d}(16.5)$ & $1.70 \mathrm{~m}$ \\
5 & $1.98 \mathrm{~m}$ & $1.96 \mathrm{~d}(10.0)$ & $5.44 \mathrm{~d}(16.0)$ \\
6 & $1.75 \mathrm{~d}(12.0)$ & $0.29 \mathrm{dd}(10.0,9.5)$ & $5.13 \mathrm{dd}(16.0,10.0)$ \\
7 & $0.50 \mathrm{dd}(12.0,9.5)$ & $0.57 \mathrm{~m}$ & $2.23 \mathrm{~m}$ \\
8 & $0.81 \mathrm{~m}$ & $0.98 \mathrm{~m}$ & $2.07 \mathrm{~m}$ \\
& $0.99 \mathrm{~m}$ & $1.90 \mathrm{~m}$ & $2.27 \mathrm{~m}$ \\
9 & $2.08 \mathrm{~m}$ & $1.59 \mathrm{~m}$ & $4.90 \mathrm{brd}(11.5)$ \\
12 & $2.32 \mathrm{dd}(13.0,6.5)$ & $1.89 \mathrm{~m}$ & $1.11 \mathrm{~s}$ \\
13 & $2.44 \mathrm{t}(13.0)$ & $1.03 \mathrm{~s}$ & $1.16 \mathrm{~s}$ \\
14 & $1.07 \mathrm{~s}$ & $1.08 \mathrm{~s}$ & $1.53 \mathrm{~s}$ \\
& $1.01 \mathrm{~s}$ & $1.32 \mathrm{~s}$ & $1.37 \mathrm{~s}$ \\
15 & $4.97 \mathrm{~s}$ & & \\
\hline$-O \mathrm{OH}$ & $4.99 \mathrm{~s}$ & $1.37 \mathrm{~s}$ &
\end{tabular}

Figure 4. Key NOESY correlations for 7.

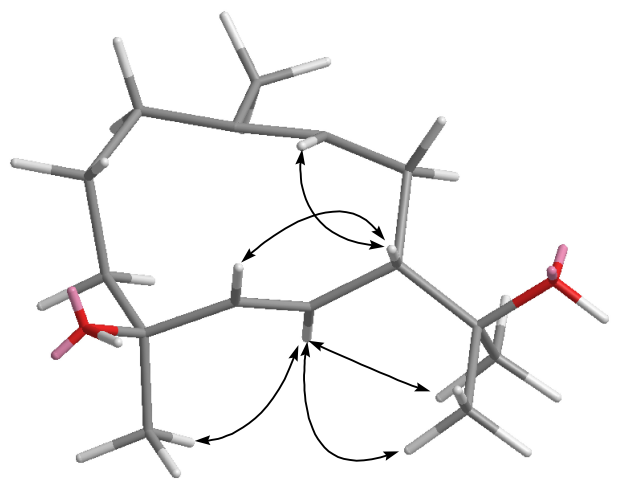

7

Cytotoxicity of compounds 1-7 against the proliferation of a limited panel of cancer cell lines, including human cervical epitheloid (HeLa), liver (SK-Hep1), and melanin (B-16) carcinoma cells, 
was evaluated. The results showed all of compounds were not cytotoxic toward these three cancer cell lines. The anti-inflammatory activities of 1-7 against the accumulation of pro-inflammatory iNOS and COX-2 proteins in RAW264.7 macrophage cells were evaluated by Western blot analysis. It was found that 1-7 could not reduce the accumulation of iNOS protein induced by LPS. At a concentration of 1 $\mu \mathrm{M}$, only compound 1 could reduce the level of LPS-induced COX-2 to $36.6 \pm 3.8 \%$. At a concentration of $10 \mu \mathrm{M}$, compounds $\mathbf{1}, \mathbf{3}$, and 4 reduced the accumulation of LPS-induced COX-2 to $8.7 \pm 4.5 \%, 61.0 \pm 6.0 \%$, and $83.4 \pm 6.4 \%$, respectively. At a concentration of $100 \mu \mathrm{M}, \mathbf{1}-\mathbf{4}$ could further reduce the levels of induced COX-2 to $1.7 \pm 1.3 \%, 17.6 \pm 2.2 \%, 32.8 \pm 3.2 \%$, and $71.3 \pm 7.2 \%$, respectively, in comparison with those of control cells stimulated with LPS only. Thus, compound 1 might be considered to be a promising COX-2 inhibiting agent.

\section{Experimental Section}

\subsection{General Experimental Procedures}

Optical rotations were measured on a JASCO P-1020 polarimeter. IR spectra were recorded on a JASCO FT/IR-4100 infrared spectrophotometer. The NMR spectra were recorded on a Varian Unity INOVA 500 FT-NMR at $500 \mathrm{MHz}$ for ${ }^{1} \mathrm{H}$ and $125 \mathrm{MHz}$ for ${ }^{13} \mathrm{C}$, in $\mathrm{CDCl}_{3}$ using TMS as internal standard. LRMS and HRMS were obtained by ESI on a Bruker APEX II mass spectrometer, or by EI on a JEOL-SX/SX 102A mass spectrometer. Silica gel 60 (Merck, 230-400 mesh) was used for column chromatography. Precoated silica gel plates (Merck, Kieselgel $60 \mathrm{~F}_{254}, 0.2 \mathrm{~mm}$ ) were used for analytical TLC. High-performance liquid chromatography was performed on a Hitachi L-6250 HPLC apparatus with a merck Hibar Si-60 column $(250 \times 21 \mathrm{~mm}, 7 \mu \mathrm{m})$.

\subsection{Animal Material}

Sinularia lochmodes was collected by hand using SCUBA off the northeast corner of Taiwan, in May 2004, at a depth of 10 to $15 \mathrm{~m}$, and stored in a freezer until extraction. A voucher sample was deposited at the Department of Marine Biotechnology and Resources, National Sun Yat-sen University (specimen No. 20040516-3).

\subsection{Extraction and Separation}

The frozen bodies of $S$. lochmodes (139.4 g) were minced and extracted with ethyl acetate. The organic extract $(4.87 \mathrm{~g})$ of the organsim was fractionated by silica gel column chromatography to afford 22 fractions (Fractions A to V). Fraction D, eluted with $n$-hexane-EtOAc (60:1), was purified by normal-phase HPLC ( $n$-hexane-EtOAc, 60:1) to afford $1(3.5 \mathrm{mg})$. Fraction G, eluted with $n$-hexane-EtOAc (20:1), was purified by normal-phase HPLC ( $n$-hexane-EtOAc, 30:1) to afford 2 $(1.5 \mathrm{mg})$. Fraction K, eluted with $n$-hexane-EtOAc $(2: 1)$, was purified by normal-phase HPLC ( $n$-hexane-EtOAc, 3:1) to afford $3(2.4 \mathrm{mg}), \mathbf{4}(1.2 \mathrm{mg})$, and $5(2.0 \mathrm{mg})$. Fraction M, eluted with $n$-hexane-EtOAc (1:2), was purified by normal-phase HPLC ( $n$-hexane-EtOAc, 1:1) to afford 6 (1.6 mg), and 7 (4.2 $\mathrm{mg})$.

Lochmolin A (1): colorless oil; $[\alpha]^{26}{ }_{\mathrm{D}}=-89\left(c 0.5, \mathrm{CHCl}_{3}\right) ;{ }^{1} \mathrm{H}$ and ${ }^{13} \mathrm{C}$ NMR data, see Tables 1 and 2; EIMS (70 eV) $m / z 234[\mathrm{M}]^{+}$; HREIMS $m / z 234.1620$ (calcd for $\mathrm{C}_{15} \mathrm{H}_{22} \mathrm{O}_{2}, 234.1621$ ). 
Lochmolin B (2): colorless oil; $[\alpha]^{26}{ }_{\mathrm{D}}=-173\left(c 0.8, \mathrm{CHCl}_{3}\right.$ ); IR (neat, $\left.\mathrm{CHCl}_{3}\right) v_{\max } 3437$ (broad) cm ${ }^{-1}$; ${ }^{1} \mathrm{H}$ and ${ }^{13} \mathrm{C}$ NMR data, see Tables 1 and 2; ESIMS $m / z 289[\mathrm{M}+\mathrm{Na}]^{+}$; HRESIMS $m / z 289.2147$ (calcd for $\mathrm{C}_{17} \mathrm{H}_{30} \mathrm{O}_{2} \mathrm{Na}, 289.2143$ ).

Lochmolin C (3): colorless oil; $[\alpha]^{26}{ }_{\mathrm{D}}=-261\left(c 0.6, \mathrm{CHCl}_{3}\right.$ ); IR (neat, $\left.\mathrm{CHCl}_{3}\right) v_{\max } 3437$ (broad) $\mathrm{cm}^{-1}$; ${ }^{1} \mathrm{H}$ and ${ }^{13} \mathrm{C}$ NMR data, see Tables 1 and 2; ESIMS $m / z 275[\mathrm{M}+\mathrm{Na}]^{+}$; HRESIMS $m / z 275.1622$ (calcd for $\mathrm{C}_{15} \mathrm{H}_{24} \mathrm{O}_{3} \mathrm{Na}, 275.1623$ ).

Lochmolin D (4): colorless oil; $[\alpha]^{26}{ }_{\mathrm{D}}=-66\left(c\right.$ 2.0, $\mathrm{CHCl}_{3}$ ); IR (neat, $\mathrm{CHCl}_{3}$ ) v $v_{\max } 3406$ (broad) $\mathrm{cm}^{-1}$; ${ }^{1} \mathrm{H}$ and ${ }^{13} \mathrm{C}$ NMR data, see Tables 1 and 2; ESIMS $m / z 275[\mathrm{M}+\mathrm{Na}]^{+}$; HRESIMS $m / z$ 275.1622 (calcd for $\mathrm{C}_{15} \mathrm{H}_{24} \mathrm{O}_{3} \mathrm{Na}, 275.1623$ ).

Lochmolin E (5): colorless oil; $[\alpha]^{26}{ }_{\mathrm{D}}=-66\left(c\right.$ 2.0, $\mathrm{CHCl}_{3}$ ); IR (neat, $\left.\mathrm{CHCl}_{3}\right) v_{\max } 3448$ (broad) $\mathrm{cm}^{-1}$; ${ }^{1} \mathrm{H}$ and ${ }^{13} \mathrm{C}$ NMR data, see Tables 1 and 3; ESIMS $m / z 275[\mathrm{M}+\mathrm{Na}]^{+}$; HRESIMS $m / z 275.1623$ (calcd for $\mathrm{C}_{15} \mathrm{H}_{24} \mathrm{O}_{3} \mathrm{Na}, 275.1621$ ).

Lochmolin F (6): colorless oil; $[\alpha]^{26}{ }_{\mathrm{D}}=-75\left(c 0.7, \mathrm{CHCl}_{3}\right.$ ); IR (neat, $\left.\mathrm{CHCl}_{3}\right) v_{\max } 3396$ (broad) $\mathrm{cm}^{-1}$; ${ }^{1} \mathrm{H}$ and ${ }^{13} \mathrm{C}$ NMR data, see Tables 1 and 3; EIMS (70eV) $\mathrm{m} / \mathrm{z} 236[\mathrm{M}]^{+}$; HREIMS $\mathrm{m} / \mathrm{z} 236.1774$ (calcd for $\mathrm{C}_{15} \mathrm{H}_{24} \mathrm{O}_{2}, 236.1777$ ).

Lochmolin G (7): colorless oil; $[\alpha]^{26}{ }_{\mathrm{D}}=-42\left(c\right.$ 0.55, $\mathrm{CHCl}_{3}$ ); IR (neat, $\left.\mathrm{CHCl}_{3}\right) v_{\max } 3303$ (broad) $\mathrm{cm}^{-1}$; ${ }^{1} \mathrm{H}$ and ${ }^{13} \mathrm{C}$ NMR data, see Tables 1 and 3; ESIMS $m / z 261[\mathrm{M}+\mathrm{Na}]^{+}$; HRESIMS $m / z 261.1828$ (calcd for $\mathrm{C}_{15} \mathrm{H}_{26} \mathrm{O}_{2} \mathrm{Na}, 261.1830$ ).

\subsection{Cytotoxicity Testing}

Cell lines were purchased from the American Type Culture Collection (ATCC). Cytotoxicity assays of compounds 1-7 were performed using the Alamar Blue assay $[9,10]$.

\subsection{In Vitro Anti-Inflammatory Assay}

Murine RAW264.7 macrophages were purchased from the American Type Culture Collection. The anti-inflammatory assay was modified from known procedure [11-13].

\section{Conclusions}

Our present investigation again demonstrated that the Formosan soft coral Sinularia lochmodes is a good source of bioactive substances. In our investigation of new and bioactive metabolites from the Formosan soft corals, this is the first study of $S$. lochmodes collected from the northeast corner of Taiwan. The aromadendrane-type compounds $\mathbf{1 - 4}$, in particular $\mathbf{1}$, might become a promising COX-2 inhibiting agent.

\section{Acknowledgements}

This work was supported by grants from the National Science Council of the Republic of China (NSC 98-2113-M-110-002-MY3) and Ministry of education (97C031702) awarded to J.-H. Sheu. 


\section{References}

1. Blunt, J.W.; Copp, B.R.; Munro, M.H.G.; Northcote, P.T.; Prinsep, M.R. Marine natural products. Nat. Prod. Rep. 2010, 27, 165-237.

2. Su, J.-H.; Tseng, Y.-J.; Huang, H.-H.; Ahmed, A.-F.; Lu, C.-K.; Wu, Y.-C.; Sheu, J.-H. 9,11-Secosterols from the soft corals Sinularia lochmodes and Sinularia leptoclados. J. Nat. Prod. 2006, 69, 850-852.

3. Tseng, Y.-J.; Ahmed, A.F.; Dai, C.-F.; Chiang, M.-Y.; Sheu, J.-H. Sinulochmodins A-C, three novel terpenoids from the soft coral Sinularia lochmodes. Org. Lett. 2005, 7, 3813-3816.

4. Tseng, Y.-J.; Ahmed, A.F.; Hsu, C.-H.; Su, J.-H.; Dai, C.-F.; Sheu, J.-H. New norcembranoids from the soft coral Sinularia lochmodes. J. Chin. Chem. Soc. 2007, 54, 1041-1044.

5. Iguchi, K.; Fukaya, T.; Yasumoto, A.; Watanabe, K. New marine sesquiterpenoids and diterpenoids from the Okinawan soft coral Clavularia koellikeri. J. Nat. Prod. 2004, 67, 577-583.

6. Wessels, M.; Konig, G.M.; Wright, A.D. 3-Acetoxyspathulenol, a new aromadendrane-type natural product from the soft coral Parerythropodium fulvum. J. Nat. Prod. 2001, 64, 370-372.

7. Stærk, D.; Skole, B.; Jørgensen, F.S.; Budnik, B.A.; Ekpe, P.; Jaroszewski, J.W. Isolation of a library of aromadendranes from Landolphia dulcis and its characterization using the VolSurf approach. J. Nat. Prod. 2004, 67, 799-805.

8. Eilbert, F.; Engler-Lohr, M.; Anke, H.; Sterner, O. Bioactive sesquiterpenes from the basidiomycete Resupinatus leightonii. J. Nat. Prod. 2000, 63, 1286-1287.

9. Nakayama, G.R.; Caton, M.C.; Nova, M.P.; Parandoosh, Z. Assessment of the Alamar Blue assay for cellular growth and viability in vitro. J. Immunol. Methods 1997, 204, 205-208.

10. O'Brien, J.; Wilson, I.; Orton, T.; Pognan, F. Investigation of the Alamar Blue (resazurin) fluorescent dye for the assessment of mammalian cell cytotoxicity. Eur. J. Biochem. 2000, 267, 5421-5426.

11. Ho, F.-M.; Lai, C.-C.; Huang, L.-J.; Kuo, T.-C.; Chao, C.-M.; Lin, W.-W. The anti-inflammatory carbazole, LCY-2-CHO, inhibits lipopolysaccharide-induced inflammatory mediator expression through inhibition of the p38 mitogen-activated protein kinase signaling pathway in macrophages. Br. J. Pharmacol. 2004, 141, 1037-1047.

12. Park, E.-K.; Shin, Y.-W.; Lee, H.-U.; Kim, S.-S.; Lee, Y.-C.; Lee, B.-Y.; Kim, D.-H. Inhibitory effect of ginsenoside $\mathrm{Rb} 1$ and compound $\mathrm{K}$ on $\mathrm{NO}$ and Prostaglandin E2 biosyntheses of RAW264.7 cells induced by lipopolysaccharide. Biol. Pharm. Bull. 2005, 28, 652-656.

13. Lowry, O.H.; Rosebrough, N.J.; Farr, A.L.; Randall, R.J. Protein measurement with the folin phenol reagent. J. Biol. Chem. 1951, 193, 265-275.

Samples Availability: Not available.

(C) 2012 by the authors; licensee MDPI, Basel, Switzerland. This article is an open access article distributed under the terms and conditions of the Creative Commons Attribution license (http://creativecommons.org/licenses/by/3.0/). 